\title{
Variability of Protection Against Different Strains Induced by a Culture Filtrate (CF) Obtained from Salmonella enteritidis
}

\author{
Keiichi UCHIYA and Hisayoshi SUGIHARA \\ Department of Microbiology, Faculty of Pharmacy, Meijo University, Tenpaku-ku Nagoya 468, Japan \\ Key words: CF of Salmonella enteritidis, Cross-protective immunity, \\ Antibody titers, Delayed footpad test
}

\begin{abstract}
Cross-protective ability against the challenge of different strains of culture filtrate (CF) obtained from Salmonella enteritidis was investigated. Immunization with CF from various smooth strains with the exception of strain 3551 which is a rough strain of $S$. enteritidis induced protective immunity against challenge with strains 2547 and 116M. However, when strains 2822, 3551 and 3975 were used as the challenge strain, no protective effect was observed. The aggulutination titers against whole cells of strain 2547 or 2822 of sera taken from the $2547 \mathrm{CF}$-immunized mice were almost the same as those of sera from the 2822 CF-immunized mice. Furthermore, delayed footpad reactivity was observed when heat-killed cells of strain 2547 or 2822 were transferred into the footpad of $2547 \mathrm{CF}$ - or $2822 \mathrm{CF}$-immunized mice. These results show that the capability of inducing protective immunity is similar between the $2547 \mathrm{CF}$ and 2822 $\mathrm{CF}$, and protection against infection with $S$. enteritidis differs in accordance with different challenge strains.
\end{abstract}

\section{Introduction}

Mouse infections with Salmonella typhimurium and S. enteritidis have been studied as a model of $S$. typhi infections in humans. It is knwon that living vaccines induce a cellular immune response, and are more effective than non-viable vaccines for the induction of immunity to Salmonella infections ${ }^{122)}$. However, there are many reports showing that non-viable vaccines give excellent levels of protection as compared with living vaccines ${ }^{3 / \sim 5}$.

Earlier studies in this laboratory have shown that immunization with Soluble Protective Antigen (SPA) separated from the culture fluids of $S$. enteritidis strain 2547 induced high levels of resistance against the challenge of $10,000 \mathrm{LD}_{50}$ of the same organism strain ${ }^{6}$. The protective capacity of SPA has been attributed to the ability to elicit both a cellular and humoral immune response in the host ${ }^{788}$. In previous studies, chemical and biological analyses of SPA indicated that SPA contains a lipid A moiety, and possesses the properties of lipopolysaccharides (LPS) isolated from S. enteritidis by chemical procedures ${ }^{910)}$. However, the LPS from $S$. enteritidis strain 2547 afforded only $80 \%$ protective immunity against the challenge of $100 \mathrm{LD}_{50}$ of the homologous bacteria. These results suggested that SPA differs markedly in physiochemical capabilities from the LPS isolated by chemical procedures, although it is certainly part of the LPS released into the liquid environment by solubilization of bacterial cell wall material.

In the present study, cross-protection tests against the challenge of different strains of CF from $S$. enteritidis were conducted to determine whether protective antigen (SPA) is released only from strain 2547 into the culture fluid. Further comparisons were made concerning the ability of inducing protective

別刷請求先：(广468)名古屋市天白区天白町八事裏山15

名城大学薬学部微生物学教室 
immunity of CF from S. enteritidis strains 2547 and 2822.

\section{Materials and Methods}

Animals

Female mice of ddy strain were purchased from the Shizuoka Laboratory Animal Center, Hamamatsu, Japan. Mice were used at the age of 7 8 weeks.

Bacterial strains

S. enteritidis strains 2547, 2822, 3551, 3975, 4129 and 116M were supplied by Niigata and Mie Prefectural Institute of Public Health, respectively. Strains 183Fu and SR144G were obtained from Fukui and Gifu Prefectural Institute of Public Health, respectively. All strains were passaged once in ddy mice before use in this study. Fresh isolates were obtained from the spleen on day 2 postinoculation. $S$. enteritidis was cultured in liver and beef papain digestion agar medium at $37^{\circ} \mathrm{C}$ for $18 \mathrm{hr}$.

Preparation of $\mathrm{CF}$

Culture filtrate (CF) was prepared as described in our previous paper ${ }^{6}$. Bacterial strains were inoculated on a synthetic TSA medium without protein, cultured at $37^{\circ} \mathrm{C}$ for 4 days, and the culture medium was filter-sterilized by a Seiz EK filter.

Determination of cross-protective immunity

Groups of five mice were immunized intraperitoneally (i.p.) with $0.5 \mathrm{ml}$ of $\mathrm{CF}$ obtained from each strain, and challenged i.p. with various doses of each strain in $0.5 \mathrm{ml}$ of $5 \%(\mathrm{~W} / \mathrm{V})$ mucin 14 days after immunization. The protective ability was demonstrated by differences between the $50 \%$ lethal dose $\left(\mathrm{LD}_{50}\right)$ of control mice and the $\mathrm{LD}_{50}$ of immunized mice.

Measurement of antibody titers

Two groups of mice were immunized i.p. with $0.5 \mathrm{ml}$ of $2547 \mathrm{CF}$ or $2822 \mathrm{CF}$. These mice were sacrificed 14 days following immunization and the serum separated. Whole-cell agglutination (WCA) titers in serum were determined by a microagglutination test as reported by Eisenstein $e a^{111}$. Heat-killed cells of strain 2547 or 2822 prepared by heating at $70^{\circ} \mathrm{C}$ for 60 min were used as antigens.

Delayed footpad test

Two groups of mice were immunized i.p. with $0.5 \mathrm{ml}$ of $2547 \mathrm{CF}$ or $2822 \mathrm{CF}$, and tested 14 days following immunization for the presence of delayed-type hypersensitivity (DTH) measured by footpad swelling. Heat-killed cells of strain 2547 or 2822 were used as antigens for eliciting the footpad response. The eliciting antigens $\left(7 \times 10^{5}\right.$ colony-forming units) suspended in $0.05 \mathrm{ml}$ saline were injected into right hind footpad, while saline was injected into the left hind footpad as a control. The thickness of the footpad was measured with dial-gauge calipers (KSM-150, KANON, Japan) just before injection of antigen and at 24 $\mathrm{hr}$ following injection. The thickness of the saline-injected footpad was subtracted from that of the antigeninjected footpad to yield the difference in footpad thickness for each mouse. DTH in nonimmunized mice was analyzed in a similar manner.

\section{Results}

Cross-protective immunity. CF obtained from various strains was tested for its ability to protect mice against challenge using different strains of S. enteritidis (Table 1). When strain 2547 or $116 \mathrm{M}$ were used as the challenge strain, protective effects were apparent in groups of mice immunized with $\mathrm{CF}$ from various smooth strains with the exception of strain 3551 (a rough strain of $S$. enteritidis). No protective effect by CF was observed with the challenge of strains 2822, 3551 and 3975.

Antibody response. Sera was collected from mice immunized 14 days previously with $2547 \mathrm{CF}$ or 2822 $\mathrm{CF}$, and the antibody titer to whole cells of strains 2547 and 2822 was determined. Table 2 indicates that $2547 \mathrm{CF}$ and $2822 \mathrm{CF}$ gave very similar agglutination titers against the whole cells of strain 2547 or 2822 . 
Table 1 Cross-protection test for immunization of culture filtrade (CF) obtained from $S$. enteritidis

\begin{tabular}{crrrrrrrr}
\hline \multirow{2}{*}{ Challenge strain } & \multicolumn{7}{c}{ Protective ability $^{\text {a) }}$ of S. enteritidis CF immunization } \\
\cline { 2 - 9 } & \multicolumn{1}{c}{ 2547 } & \multicolumn{1}{c}{ 116M } & \multicolumn{1}{c}{2822} & 3551 & 3975 & 4129 & 183Fu & SR144G \\
\hline 2547 & $>2.8$ & $>2.8$ & $>2.8$ & 1.4 & $>2.8$ & $>2.4$ & $>2.6$ & $>1.8$ \\
$116 \mathrm{M}$ & $>1.6$ & $>2.2$ & $>2.6$ & 0.6 & $>2.4$ & $>2.6$ & $>2.2$ & 1.6 \\
2822 & 0.8 & $<0.4$ & 0.6 & 0.8 & 0.8 & 1.0 & 0.8 & 0.8 \\
3551 & 0.8 & 0.8 & 1.0 & 0.4 & 1.0 & 0.8 & 0.2 & 0.2 \\
3975 & 0 & 0.6 & 0.6 & 0 & 0.4 & 0.4 & $>1.0$ & 0.2 \\
\hline
\end{tabular}

a ) Protective ability was demonstrated by differences between the $\mathrm{LD}_{50}$ of control mice and the $\mathrm{LD}_{50}$ of immunized mice, $\left(\mathrm{LD}_{50}\right.$ of immunized mice-- $10^{\mathrm{n} 1} \mathrm{mg}, \mathrm{LD}_{50}$ of control mice-- ${ }^{\mathrm{n} 2} \mathrm{mg}$, Protective ability $=$ n1-n2)

Table 2 Agglutination of immunized mice sera by culture filtrate obtained from $S$. enteritidis 2547 or 2822

\begin{tabular}{|c|c|c|c|c|c|c|c|c|c|}
\hline \multirow{2}{*}{ Antigen } & & \multicolumn{7}{|c|}{ Dilution of serum } & \multirow{2}{*}{ cont. $^{\text {c) }}$} \\
\hline & & 1 & $2^{1}$ & $2^{2}$ & $2^{3}$ & $2^{4}$ & $2^{5}$ & $2^{6}$ & \\
\hline \multirow{2}{*}{$\begin{array}{l}\text { Heat-killed } \\
\text { S. enteritidis } 2547\end{array}$} & Anti-2547 CF serum ${ }^{\text {a) }}$ & + & + & + & \pm & - & - & - & - \\
\hline & Anti-2822 CF serum ${ }^{b}$ & + & + & + & + & \pm & - & - & - \\
\hline \multirow{2}{*}{$\begin{array}{l}\text { Heat-killed } \\
\text { S. enteritidis } 2822\end{array}$} & Anti-2547 CF serum & + & + & + & \pm & - & - & - & - \\
\hline & Anti-2822 CF serum & + & + & + & \pm & - & - & - & - \\
\hline
\end{tabular}

a ) b) 2547 or $2822 \mathrm{CF}$ : Culture filtrate obtained from S. enteritidis 2547 or 2822 . Mice sera were obtained 14 days after i.p. injection of $2547 \mathrm{CF}$ or $2822 \mathrm{CF}$.

c) Cont. : Phosphate buffered saline

Table 3 Delayed footpad reaction in mice after immunization with culture filtrate obtained from $S$. enteritidis 2547 or 2822

\begin{tabular}{cccc}
\hline \multirow{2}{*}{ Antigen } & \multicolumn{3}{c}{ Delayed footpad reaction $(\times 0.1 \mathrm{~mm})$} \\
\cline { 2 - 4 } & $\begin{array}{c}\text { Mice immunized } \\
\text { with 2547 CF }\end{array}$ & $\begin{array}{c}\text { Mice immunized } \\
\text { with 2822 CF }\end{array}$ & $\begin{array}{c}\text { Nonimmunized } \\
\text { control mice }\end{array}$ \\
\hline $\begin{array}{c}\text { None } \\
\text { Heat-killed }\end{array}$ & $-0.10 \pm 0.60$ & $1.29 \pm 0.38$ & $-0.13 \pm 0.48$ \\
$\begin{array}{l}\text { S. enteritidis } 2547 \\
\text { Heat-killed }\end{array}$ & $4.25 \pm 0.25$ & $4.09 \pm 0.57$ & $1.92 \pm 0.68$ \\
S. enteritidis 2822 & $4.05 \pm 0.75$ & $3.88 \pm 0.64$ & $1.05 \pm 0.34$
\end{tabular}

a) 2547 or $2822 \mathrm{CF}$ : Culture filtrate obtained from S. enteritidis 2547 or 2822. Mice were immunized i.p. with $2547 \mathrm{CF}$ or $2822 \mathrm{CF}$, and injected into the footpad 14 days later with each antigen. Delayed footpad reaction was measured $24 \mathrm{hr}$ after elicitation with each antigen.

Mean \pm SEM

Delayed footpad reaction of $2547 \mathrm{CF}$ or $2822 \mathrm{CF}$-immunized mice. Mice were immunized with $2547 \mathrm{CF}$ or $2822 \mathrm{CF}$, and the delayed footpad reaction was measured (Table 3). When heat-killed cells of strain 2547 or 2822 were used as eliciting antigens, the DTH response was observed.The capacity of inducing the DTH response was similar between the $2547 \mathrm{CF}$ and $2822 \mathrm{CF}$.

\section{Discussion}

There are many reports showing that non-viable vaccines have the capacity to protect mice against a 
lethal Salmonella challenge ${ }^{3) \sim 51}$. Plant et al. ${ }^{12)}$ reported that a supernatant factor prepared from cultures of S. typhimurium protects mice against a subcutaneous challenge dose of $100 \mathrm{LD}_{50}$ of $S$. typhimurium. In this laboratory, it has been shown that SPA separated from the culture fluids of S. enteritidis strain 2547 protects effectively against a lethal challenge of the same organism strain ${ }^{6}$. In previous studies, chemical and biological analyses of SPA revealed the presence of LPS ${ }^{9 / 10)}$. Passive transfer of anti-SPA mouse serum was shown to protect mice against infection with $S$. enteritidis, whereas the protective ability was completely lost following absorption of the anti-SPA mouse serum with LPS extracted from S. enteritidis. In contrast to these results, SPA alone could induce significant protection against the challenge of 10,000 $\mathrm{LD}_{50}$ of $S$. enteritidis, yet LPS isolated from S. enteritidis strain 2547 by chemical procedures afforded only $80 \%$ protective immunity against the challenge of $100 \mathrm{LD}_{50}$ of the homologous bacteria. These results suggested that LPS may be an essential component for the induction of protective immunity with SPA, however SPA appeared to differ markedly in physiochemical capabilities from the LPS isolated by chemical procedures.

In this study, cross-protective ability against the challenge of different strains of CF obtained from $S$. enteritidis was investigated. As shown in the results, when strain 2547 or $116 \mathrm{M}$ were used as the challenge strain, protective effects were observed in groups of mice immunized with $\mathrm{CF}$ from various smooth strains with the exception of strain 3551 which is a rough strain of S. enteritidis (Table 1). No protective effect was observed with the challenge of strains 2822,3551 and 3975 . It was found in this study that the protective antigen (SPA) separated from culture fluids of strain 2547 is liberated into the culture fluid from various smooth strains of $S$. enteritidis by solubilization. Additionally, comparisons were made of the ability of inducing protective immunity of CF from S. enteritidis 2547 and 2822 . The CF from strain 2547 or 2822 were able to induce delayed hypersensitivity, which is regarded as a conveninet indicator of cell-mediated immunity (Table 3). The degree of delayed footpad reactivity induced by the CF and $2822 \mathrm{CF}$ appeared to be almost identical. Furthermore, the agglutination titers against whole cells of strain 2547 or 2822 of sera taken from the 2547 CF-immunized mice were almost the same as those of sera from the $2822 \mathrm{CF}$ immunized mice. These results suggest that the ability to induce protective immunity is very similar between the $\mathrm{CF}$ from various smooth strains of $S$. enteritidis.

The conclusion obtained from this study is that protection against infection with S. enteritidis will vary in accordance with different challenge strains.

\section{Acknowledgments}

Thanks are due to Dr T. Nikai for very helpful discussions, and to Miss Y. Nakamura for her assistance in the experimental work.

\section{References}

1) Ushiba, D., Saito, K., Akiyama, T., Nakano, M., Sugiyama, T. \& Shirono, S.: Studies on experimental typhoid: Bacterial multiplication and host cell response after infection with Salmonella enteritidis in mice immunized with live and killed vacines. Japan J. Microbiol., 3: 231-242, 1959.

2) Mackanes, G.B. \& Blanden, R.V.: Cellular immunity. Allergy, 11: 89-140, 1967.

3) Venneman, M.R.: Purification of immunogenically active ribonucleic acid preparations of Salmonella typimurium: molecular-sieve and anion-exchange chromtography. Infect. Immun., 5: 269-282, 1972.

4) Kuusi, N., Nurminen, M., Saxen, H., Valtonen, M. \& Helena, P.: Immunization with major outer membrane proteins in experimental Salmonellosis of mice. Infect. Immune., 25: 857-863, 1979.

5) Svenson, S.B., Nurminen, M. \& Lindberg, A.A.: Artificial Salmonella vaccines: O-antigenic oligosaccharide-protein conjugates induce protection against infection wit Salmonella typhimurium. Infect. Immun., 25: 863-872, 1979.

6) Kamiya, K., Sugihara, H. \& Tanaka, T.: Basic studies on prevention of experimental Salmonellosis (4). Purification of S. enteritidis SPA. Jap. J. A. Infect. Dis., 56: 126-133, 1982. 
7) Kamiya, K., Sugihara, H. \& Tanaka, T.: Basic studies on prevention of experimental Salmonellosis (5). Humoral immune responses in protective immunity with purified SPA of S. enteritidis. Jap. J. A. Infect. Dis., 56: 671-678, 1982.

8) Kamiya, K. \& Sugihara, H.: Basic studies on prevention of experimental Salmonellosis (6). Cellular immunity in the protective mechanism with purified SPA of Salmonella enteritidis. Jap. J. A. Infect. Dis., 57: 33-39, 1983.

9) Uchiya, K. \& Sugihara, H.: Biological and chemical studies on Soluble Protective Antigen (SPA) separated from culture supernatant fluids of Salmonella enteritidis. Jap. J. A. Infect. Dis., 64: 802-808, 1990.

10) Uchiya, K. \& Sugihara, H.: Immunological studies on Soluble Protective Antigen (SPA) separated from culture supernatant fluids of Salmonella enteritidis. Jap. J. A. Infect. Dis., 64: 973-979, 1990.

11) Eisenstein, T.K., Killar, L.M. \& Sultzer, B.M.: Immunity of infection with Salmonella typhimurium: Mouse-strain differences in vaccine- and serum-mediated protection. J. Infect. Dis., 150: 425-435, 1984.

12) Plant, J., Glynn, A.A. \& Wilson, B.M.: Protective effects of a supernatant factor from Salmonella typhimurium on Salmonella typhimurium infection of inbred mice. Infect. Immun., 22: 125-131, 1978.

\title{
Salmonella enteritidis から得られた培養濾液によって \\ 誘導される感染防御成立に括ける菌株間の相異
}

\author{
名城大学薬学部微生物学教室 \\ 打矢恵一杉原久義 \\ (平成 2 年 5 月 17 日受付) \\ (平成 2 年 6 月 27 日受理)
}

\section{S. enteritidis から得られた培養濾液 (Culture} filtrate：以下 CF と略す）のあらゆる菌株の攻撃 に対する交叉防御能力を調べた結果, rough strainである3551株以外, 用いたすべての smooth strain からのCFで免疫する事によって 2547,116M 株の攻撃に対して感染防御が成立し た。一方，2822，3551，3975株での攻撃に対して は, 防御効果はまったく得られなかった。 そこで, 2547株の CF で免疫したマウスから得られた血清 の2547，2822株の熱処理死菌体に対する凝集素価
を調べた結果，2822株の CF で免疫したマウスか ら得られた血清のそれと汪とんど同じ值を示し た.さらに, 2547あるいは2822株の CF で免疫した マウスに対する遅延型足蹠反応を調べた結果, 誘 出抗原としての2547, 2822株の熱処理死菌体に対 して両方共に拈いて反応が見られ, 又, その值に ほとんど差はなかった。これらの結果より, 防御 免疫を誘導する能力は2547,2822株の CF では違 いがなく, S. enteritidis 感染に対する防御は, 攻 撃菌株の種類によって異なるといら事が判った。 